\title{
Optimization of Various Parameter on Bearing Strength of Natural Fiber Reinforced Composites Using Statistical Methods
}

\author{
Sanjay T Naikwade, R.R. Malagi
}

\begin{abstract}
In the recent studies, Jute fiber is seen as a commonly used reinforcement material to develop reinforced plastics for their mechanical applications. Due to its availability at low cost, biodegradable nature, and possessing moderate mechanical properties, it is preferred in the development of polymer matrix composites. Bolted joints are vastly used in many application and constitute an integral part of structural components. The reliability of the Bolted joint depends on bearing strength, which is remarkably influenced by various parameters. The proposed work presents the experimental study on the impact of different factors such as width to hole diameter $(W / D)$ ratio, edge distance to hole diameter $(E / D)$ ratio, varied as $2.6,2.8,3.25$ hole diameter varies $5,7,8$ respectively. The bearing test was carried out in accordance with the ASTM standard D 953 to determine the specific bearing strength of the composite. Using the collars in Bolted joints directly influences the bearing strength and load carrying capacity. In this study with collar of 3.25 of $W / D$ and $E / D$ ratio specimen can bear more load and safe the specimen bearing failure mode compared to $3.25 W / D$ and $E / D$ ratio of composite specimen without collar. Hence using collar in joints carries more load and avoids sudden failures. These results were also proven with the support of statistical tools.
\end{abstract}

Keywords: Jute Fiber, Composite Material, Reinforcement, Biodegradable, Bearing Strength,

\section{INTRODUCTION}

A composite material is made of two or more constituent materials having significantly different chemical and physical properties [1]. Since, composite materials are available at low cost, renewable, recyclable, and biodegradable in nature, low cost, totally or somewhat recyclable, and biodegradable, the usage of polymer composite materials is increasing very vastly in various mechanical field. Plants, for example, flax, cotton, hemp, jute, sisal, kenaf, pineapple, ramie, bamboo, banana, and so on., just as wood, utilized from days of yore as a wellspring of lignocellulosic strands, are increasingly more frequently connected as the fortification of composites. Bolted joints are detachable joints consisting of two or more individual component parts with latter being connected with each other in different by means of standardized fasteners, such as pins. Bearing strength(BS) of bolt can be defined as maximum stress load that the unit can bear before failure of structure. The numerical as well as experimental results revealed that with increasing ratio of E/D ranged from about 2 to 4 , cleavage failure gradually switches to

Revised Manuscript Received on August 25, 2019

Mr. Sanjay T Naikwade, Research Scholar VTU- Belgavi (Karnataka),

Dr. R.R. Malagi, Professor, Dept. Of P.G. Studies VTU Belagavi(Karnataka), the bearing failure. For the bolted joints made of X850 carbon/epoxy composites with symmetric lay ups, an economic and suitable ratio of $\mathrm{E} / \mathrm{D}$ is provided [2] The construction of composite structures is one of the main problems to design efficient structural attachments. In this work, advancements in analytical approaches, experimental tests and finite element analysis (FEA) associated with composite bolt designing have been studied [3].The two different geometrical parameters were the $\mathrm{E} / \mathrm{D}$ and W/D ratio was chosen from 2 to 5 in glass fiber epoxy laminates. In line with experimental results, failure mode and bearing strength are strongly motivated through both material parameter and geometrical parameters [4]. And, if geometrical parameters of routinely fastened composite joints are varied, the failure modes and loads are strictly motivated from this variation [5]. To study the mode of failure load and failure in a composite plate of aluminum-glass-epoxy, mounted by a bolt mechanically. Mixed modes are tracked for E / D and W / D equivalent to 2 to 5 and 3 to 4 respectively, particularly bearing and net tension. Preload moments boost the composite laminate's failure strengths[6,7]. The ratio of the distance between pin center and sample end, to pin diameter $\mathrm{E} / \mathrm{D}$ and the ratio of sample width to pin diameter W/D, had been changed comprehensively and maximum bearing failure loads were acquired for $\left[\left(0^{\circ} / 90^{\circ}\right) /(+/-45)\right]_{2 \mathrm{~s}}$ lay-up with geometric parameters of $\mathrm{D}=10 \mathrm{~mm}$ and $\mathrm{W} / \mathrm{D}=2$. The experimental results obtained shows that the magnitudes of bearing strength in single bolt composite joints are strictly affected by the increased value of applied preload moment, changing W/D and E/D ratio also ply orientation. $[8,9]$. From previous literature, it was found that experimental work on Bolted joints is found to be very scanty. Henceforth, we are conducting experimental work to analyze the bearing strength of natural fiber composite by using statistical techniques.

\section{A. Materials}

\section{MATERIALS AND METHODS}

Jute fiber is arrived out

of two herbaceous annual plants, white Corchoruscapsularis (white jute) created from Asia and Corchorusolitorius (Tossa jute) from Africa. Epoxy resins, traditionally are done by way of reacting epichlorohydrin together with bis-phenol A, which are linear

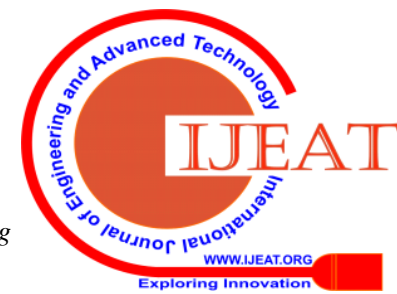


polymers that cross-link, constructing thermosetting resins essentially via the reaction together with the hardeners. Hand layup process is adopted for simple and material can be easily handled.

\section{B. Specimen preparation}

Jute fiber is cut according to the required dimension. The surface of the jute was initially smeared with a releasing agent to prevent the composite from sticking on to the sheet.Epoxy L-12 and hardener K-6 were mixed in a container and stirred well for 5-7 minutes. The prepared mixture is applied to jute by hand layup technique.Then composite board is pressed in hydraulic press. The composite board is cured up to 24 hours at room temperature in hydroulic press. The composite board is removed from the hydroulic press.After drying the samples were cut in accordance with ASTM D 953 standards and specimens are prepared as per requirements shown in fig. 1 .
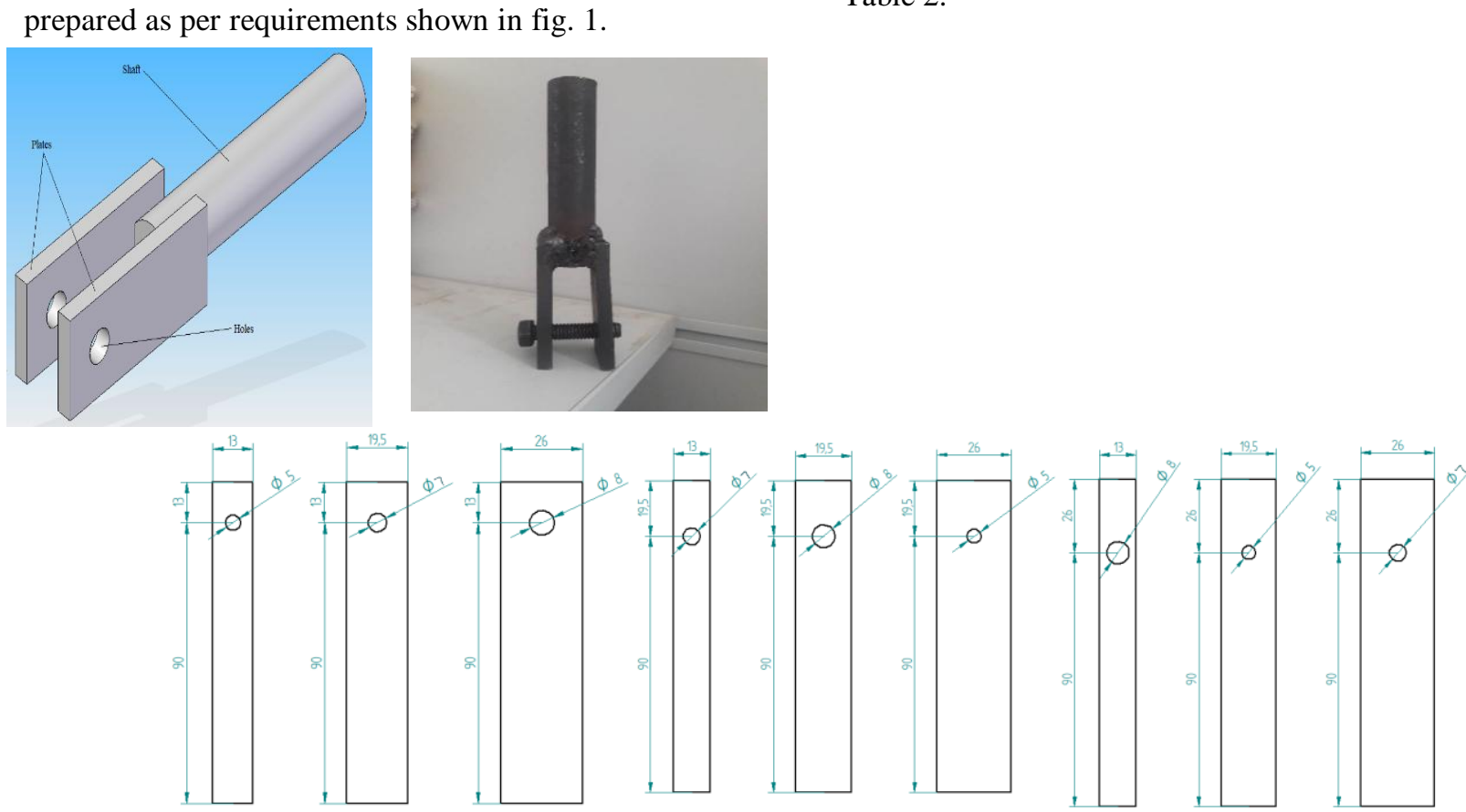

Fig. 2 Dimension of single Bolted specimens

\begin{tabular}{|l|l|l|l|l|l|l|}
\hline \multicolumn{7}{|c|}{ Table 1 Combination of Level and factors } \\
\hline \multirow{2}{*}{$\begin{array}{l}\text { Sl } \\
\text { No }\end{array}$} & Code & Factors & \multicolumn{4}{|l|}{ Levels } \\
\cline { 4 - 7 } & & A & $\begin{array}{l}\text { W/D } \\
\text { ratio }\end{array}$ & $\begin{array}{l}2 . \\
6\end{array}$ & 2.8 & 3.25 \\
\hline 2 & B & $\begin{array}{l}\text { E/D } \\
\text { ratio }\end{array}$ & 2. & 2.8 & 3.25 \\
\hline 3 & C & $\begin{array}{l}\text { Hole } \\
\text { diamete } \\
\text { r }\end{array}$ & 5 & 7 & 8 \\
\hline
\end{tabular}

Table 2 Orthogonal array for $L_{9}$ Taguchi design

\begin{tabular}{|c|c|c|c|}
\hline \multirow{2}{*}{$\begin{array}{c}\text { Experimental } \\
\text { Number }\end{array}$} & \multicolumn{3}{|c|}{ Column } \\
\cline { 2 - 4 } & A & B & C \\
\hline 1 & 1 & 1 & 1 \\
\hline 2 & 1 & 2 & 2 \\
\hline 3 & 1 & 3 & 3 \\
\hline 4 & 2 & 1 & 2 \\
\hline 5 & 2 & 2 & 3 \\
\hline 6 & 2 & 3 & 1 \\
\hline 7 & 3 & 1 & 3 \\
\hline 8 & 3 & 2 & 1 \\
\hline 9 & 3 & 3 & 2 \\
\hline
\end{tabular}

\section{B. Material Failure}

(a)

(b)

(c) 

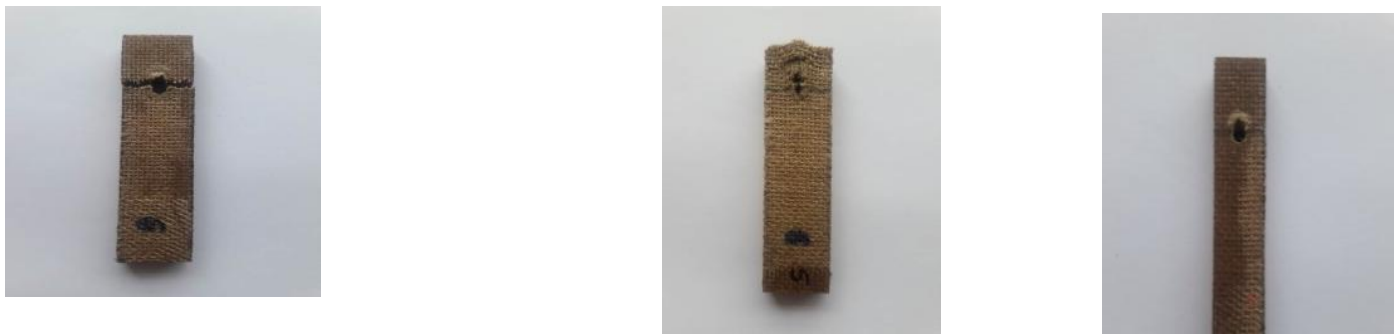

Fig. 3 Modes of failure (a) Net-tension, (b) Shear out, (c) Bearing

\section{RESULTS AND DISCUSSIONS}

The empirical results are analyzed with the use of Taguchi method and the important parameters affecting Bolted joint strength of a composite have been identified.

\section{A. Taguchi Method Results}

The experimental load carrying capacity and calculated joint tensile strength are presented in the following table 3 and 4.

Table: 3 Experimental setup on the basis of Taguchi orthogonal array $\left(\mathrm{L}_{9}\right)$ without washer

\begin{tabular}{|c|c|c|c|c|c|c|c|}
\hline Sl. No & $\begin{array}{c}\text { W/D } \\
\text { Ratio }\end{array}$ & $\begin{array}{c}\text { E/D } \\
\text { Ratio }\end{array}$ & $\begin{array}{c}\text { Hole } \\
\text { Diameter }\end{array}$ & $\begin{array}{c}\text { Failure } \\
\text { Load } \\
(\mathbf{k N})\end{array}$ & $\begin{array}{c}\text { Deflection } \\
(\mathbf{m m})\end{array}$ & $\begin{array}{c}\text { Bearing } \\
\text { Strength } \\
\left(\mathbf{N} / \mathbf{m m}^{2}\right)\end{array}$ & $\begin{array}{c}\text { Mode of } \\
\text { Failure }\end{array}$ \\
\hline 1 & 2.6 & 2.6 & 5 & 5.05 & 9.5 & 101.20 & $\begin{array}{c}\text { Net } \\
\text { tension }\end{array}$ \\
\hline 2 & 2.8 & 2.6 & 7 & 3.5 & 5.5 & 50.55 & Bearing \\
\hline 3 & 3.25 & 2.6 & 8 & 3.5 & 3 & 43.75 & Bearing \\
\hline 4 & 2.6 & 2.8 & 7 & 2.2 & 7.01 & 31.42 & $\begin{array}{c}\text { Net } \\
\text { tension }\end{array}$ \\
\hline 5 & 2.8 & 2.8 & 8 & 4.4 & 7.1 & 55 & $\begin{array}{c}\text { Net } \\
\text { tension }\end{array}$ \\
\hline 6 & 3.25 & 2.8 & 5 & 4.1 & 6.1 & 82 & Bearing \\
\hline 7 & 2.6 & 3.25 & 8 & 1.5 & 2.5 & 18.75 & $\begin{array}{c}\text { Net } \\
\text { tension }\end{array}$ \\
\hline 8 & 2.8 & 3.25 & 5 & 3.8 & 2.6 & 76 & Bearing \\
\hline 9 & 3.25 & 3.25 & 7 & 2.8 & 8.2 & 46.60 & Shear out \\
\hline
\end{tabular}

Table: 4 Experimental setup based on Taguchi orthogonal array $\left(\mathrm{L}_{9}\right)$ with washer

\begin{tabular}{|c|c|c|c|c|c|c|c|}
\hline Sl. No & $\begin{array}{l}\text { W/D } \\
\text { Ratio }\end{array}$ & $\begin{array}{c}\text { E/D } \\
\text { Ratio }\end{array}$ & $\begin{array}{c}\text { Hole } \\
\text { Diameter }\end{array}$ & $\begin{array}{c}\text { Failure } \\
\text { Load } \\
(\mathbf{k N})\end{array}$ & $\begin{array}{l}\text { Deflection } \\
(\mathrm{mm})\end{array}$ & $\begin{array}{l}\text { Bearing } \\
\text { Strength } \\
\left(\mathrm{N} / \mathrm{mm}^{2}\right)\end{array}$ & $\begin{array}{c}\text { Mode of } \\
\text { Failure }\end{array}$ \\
\hline 1 & 2.6 & 2.6 & 5 & 4.3 & 9.7 & 86 & $\begin{array}{c}\text { Net } \\
\text { tension }\end{array}$ \\
\hline 2 & 2.8 & 2.6 & 7 & 7.5 & 9.6 & 107.52 & $\begin{array}{c}\text { Net } \\
\text { tension }\end{array}$ \\
\hline 3 & 3.25 & 2.6 & 8 & 5.5 & 2.7 & 68 & Shear out \\
\hline 4 & 2.6 & 2.8 & 7 & 3.4 & 5.3 & 48.02 & $\begin{array}{c}\text { Net } \\
\text { tension }\end{array}$ \\
\hline 5 & 2.8 & 2.8 & 8 & 5.5 & 6.9 & 68 & $\begin{array}{c}\text { Net } \\
\text { tension }\end{array}$ \\
\hline 6 & 3.25 & 2.8 & 5 & 5.7 & 3.8 & 114 & Bearing \\
\hline 7 & 2.6 & 3.25 & 8 & 1.8 & 5.4 & 22.5 & $\begin{array}{c}\text { Net } \\
\text { tension }\end{array}$ \\
\hline 8 & 2.8 & 3.25 & 5 & 5.5 & 4.1 & 40 & Bearing \\
\hline 9 & 3.25 & 3.25 & 7 & 9.5 & 8.8 & 135 & $\begin{array}{c}\text { Net } \\
\text { tension }\end{array}$ \\
\hline
\end{tabular}

B. Load displacement plots for single Bolted joints 
Optimization of Various Parameter on Bearing Strength of Natural Fiber Reinforced Composites Using Statistical Methods

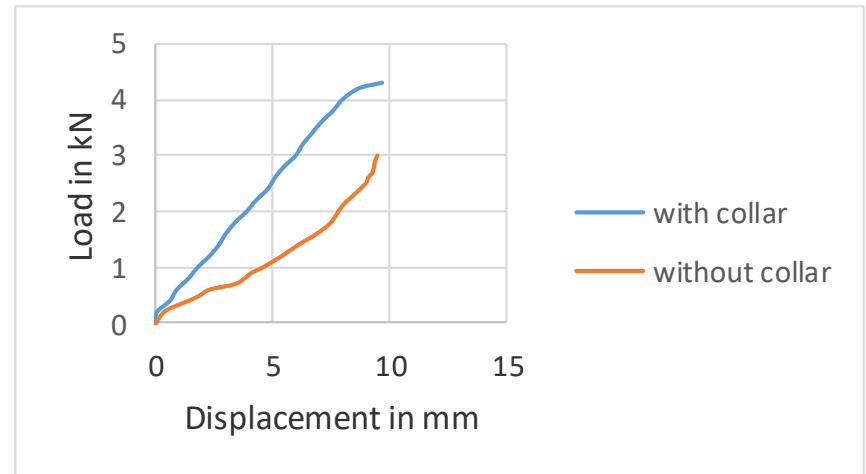

Fig 4 Plot of load v/s displacement for hole diameter of $5 \mathrm{~mm}$

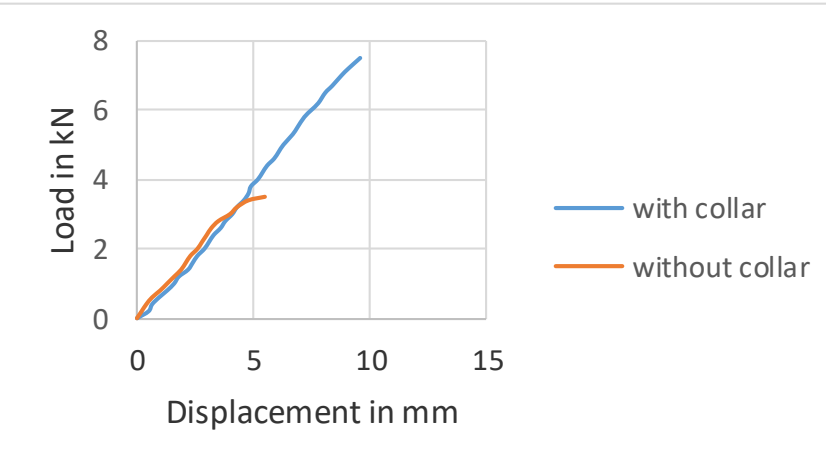

Fig 5 Plot of load v/s displacement for hole diameter of $7 \mathbf{m m}$

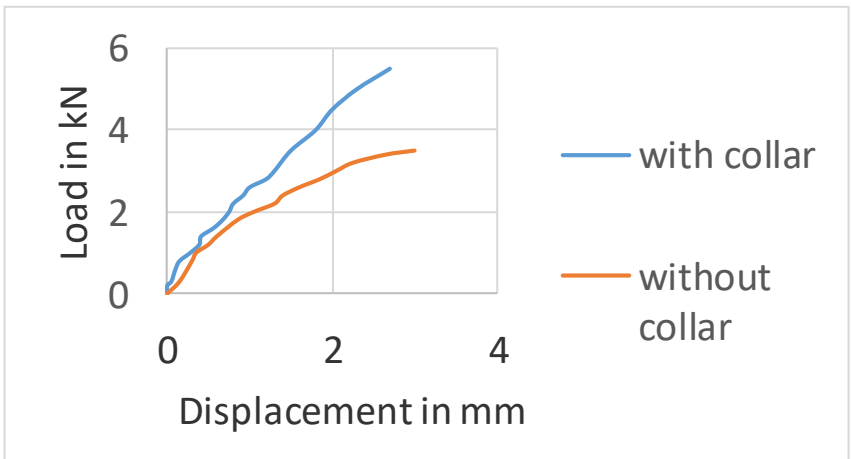

Fig 6 Plot of load v/s displacement for hole diameter of $8 \mathrm{~mm}$

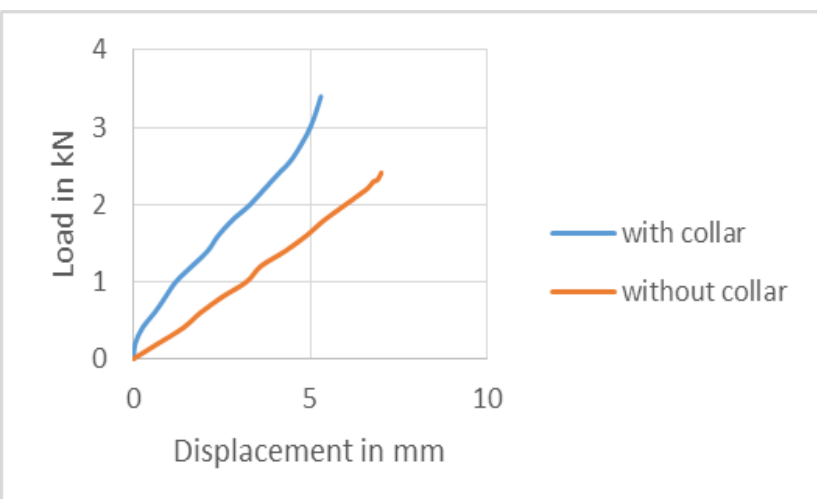

Fig 7 Plot of load v/s displacement for hole diameter of $7 \mathrm{~mm}$

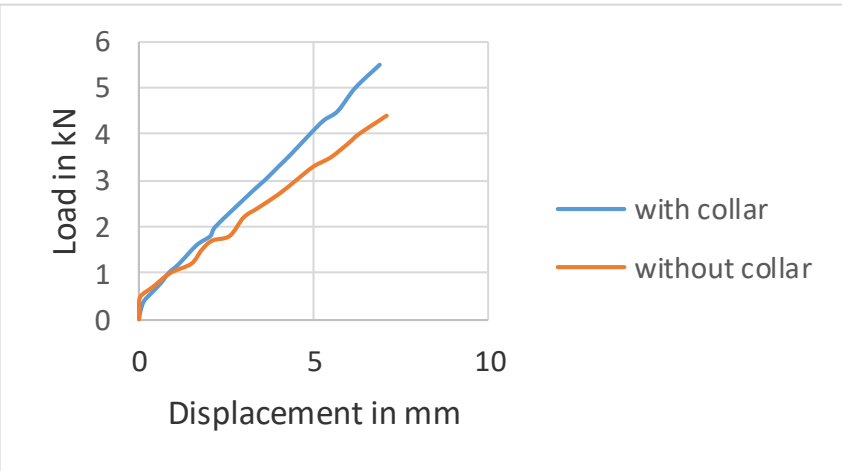

Fig 8 Plot of load v/s displacement for hole diameter of $8 \mathbf{m m}$

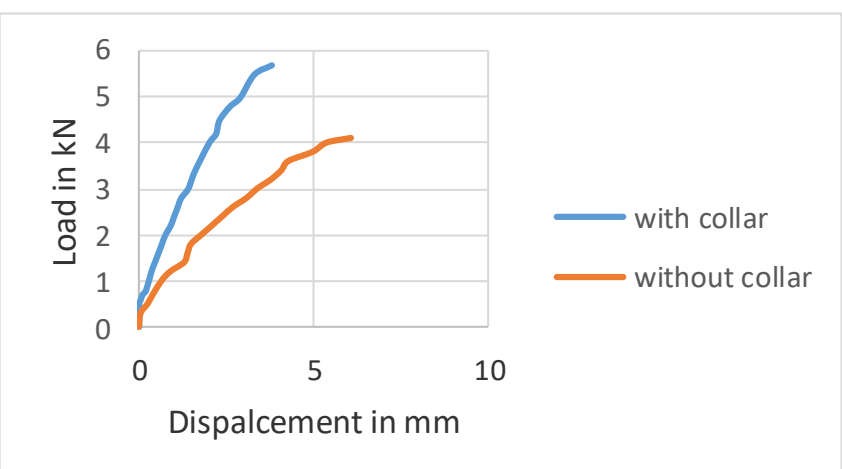

Fig 9 Plot of load v/s displacement for hole diameter of $5 \mathrm{~mm}$

Fig 10 Plot of load v/s displacement for hole diameter of $8 \mathrm{~mm}$ 


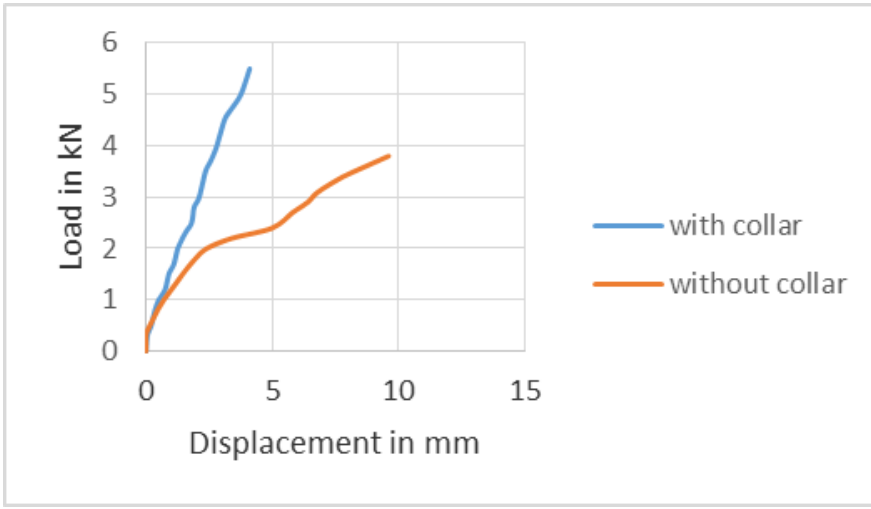

Fig 11 Plot of load v/s displacement for hole diameter of $5 \mathrm{~mm}$

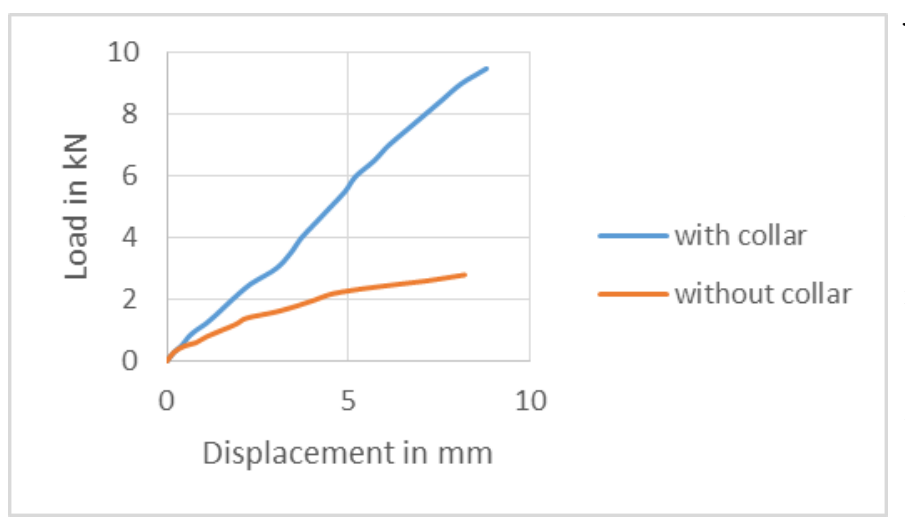

Fig 12 Plot of load v/s displacement for hole diameter of $7 \mathbf{m m}$

Above figures represents the load $\mathrm{v} / \mathrm{s}$ displacement plot obtained from experimental test for Bolted joint for W/D ratio, E/D ratio and hole diameter.In the plot blue and red colour line represents with and without collars specimens load carrying capacity in $\mathrm{Y}$ axis and displacement $\mathrm{X}$ axis. From the experimental result found that as the W/D ratio increases load carrying capacity also increases, the E/D ratio parameter slightly influences the load carrying capacity of natural composite specimen and the hole diameter also plays an important role in load carry were load carry capacity decreases with increase in hole diameter.Figure 10 the specimen carries low load. From above graphs we conclude that specimen which have collar can bear the maximum load compare to without collar specimen.

From fig 12. The with collar specimen have more load carrying capacity of $9.5 \mathrm{kN}$ and the same specimen without collar carries less load of $2.8 \mathrm{kN}$. Graphs clearly shows that load carrying capacity of joints directly depends on W/D ratio rather than E/D ratio and hole diameter.

\section{MATH STATISTICAL SURVEY}

\section{A. ANALYSIS OF VARIANCE (ANOVA)}

The Analysis of Variance (ANOVA) - is utilized to analyse results of the OA experiment and to evaluate the contribution of influencing factor(s) on the capacity of Load carrying and Tensile strength of the composite joint.

ANOVA for Load carrying capacity

Table: 5 ANOVA for Load carrying capacity $(\mathrm{kN})$ without collar

\begin{tabular}{|c|c|c|c|c|c|c|c|}
\hline Source & D F & Seq SS & Adj SS & Adj MS & F & P & $\begin{array}{c}\text { \% of confidence } \\
\text { level }\end{array}$ \\
& & & & & & & \\
\hline W/D & 2 & 125.24 & 125.24 & 62.62 & 0.67 & 0.598 & 47.02 \\
\hline E/D & 2 & 275.54 & 275.54 & 137.77 & 1.48 & 0.403 & 29.56 \\
\hline Hole dia & 2 & 345.07 & 345.07 & 172.53 & 1.85 & 0.350 & 13.43 \\
\hline Error & 2 & 186.07 & 186.07 & 93.03 & & & 9.96 \\
\hline Total & 8 & 931.91 & & & & & 100 \\
\hline
\end{tabular}

$\mathrm{DF}=$ degrees of freedom, $\mathrm{SS}=$ sum of squares, $\mathrm{MS}=$ mean hole diameter $(13.43 \%)$ and $\mathrm{E} / \mathrm{D}$ ratio square, $\mathrm{F}=$ variance \& P-test

has little impact on the ability of the load carrying.

It can be concluded from the Table 5 that the main factors affecting the load carrying capacity are the W/D ratio $(47.02 \%)$ and

Table: 6 ANOVA for Load carrying capacity $(\mathrm{kN})$ with collar

\begin{tabular}{|c|c|c|c|c|c|c|c|}
\hline Source & D F & Seq SS & Adj SS & Adj MS & F & P & $\begin{array}{c}\text { \% of confidence } \\
\text { level }\end{array}$ \\
& & & & & & & \\
\hline W/D & 2 & 2347.6 & 2347.6 & 1173.8 & 4.93 & 0.169 & 59.41 \\
\hline E/D & 2 & 137.6 & 137.6 & 68.8 & 0.29 & 0.776 & 6.48 \\
\hline Hole dia & 2 & 989.6 & 989.6 & 494.8 & 2.08 & 0.325 & 25.047 \\
\hline Error & 2 & 476.2 & 476.2 & 238.1 & & & 9.052 \\
\hline Total & 8 & 3950.9 & & & & & 100 \\
\hline
\end{tabular}

hole diameter has little effect on strength of the joint and

Table 6 shows the ANOVA for the bearing strength and it can be surmise that the main factors affecting the load carrying capacity are the W/D ratio $(59.41 \%)$ and E/D ratio $(6.48 \%)$.This analysis concludes that other two factors that is 


\section{B. Main Effect Plots}

As shown in the Figure 13 for main effect plots, when the line is horizontal,

it relates to the absence of any major impact. The load carrying ca pacity is affected in the same manner by each factor level and is th e same across all factor concentrations.

\section{Main Effect Plots for Load Carrying Capacity (N) with} collar

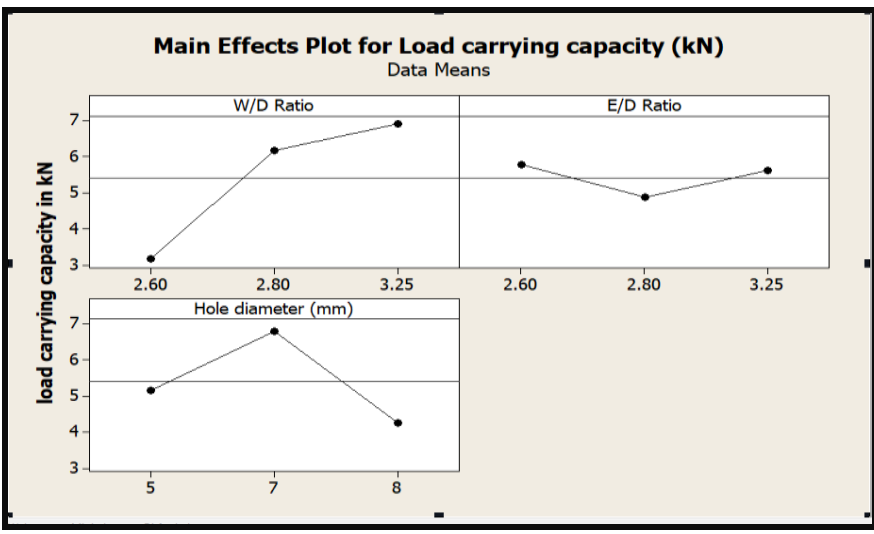

Fig 13 Graphs for mean load carrying capacity v/s W/D, E/D and hole diameter

The main impact of the W/D ratio presented in the graph fig 13. the load carrying capacity of a joint increased slightly linear with the increasing W/D ratio. From the ANOVA and main effect plots shows that as W/D ratio increases load carrying capacity and bearing strength also increases.

D. Main Effect Plots for Load Carrying Capacity (N) without collar

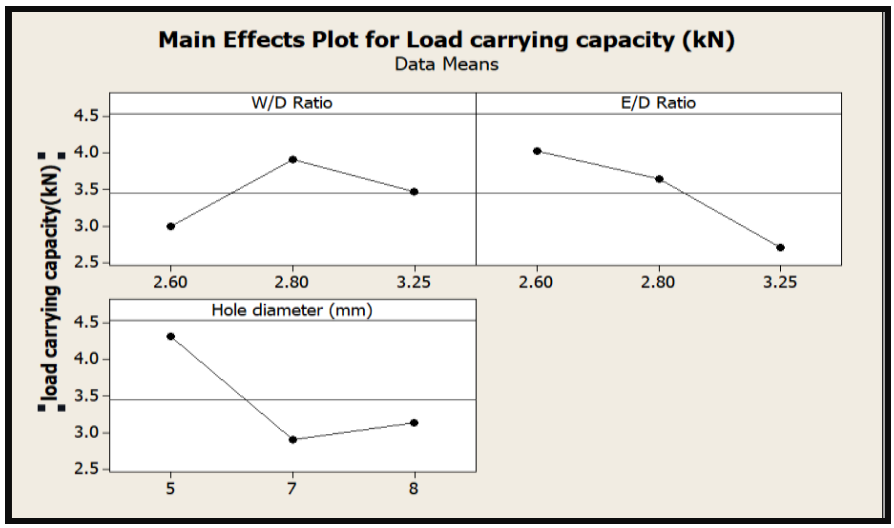

Fig 14 Graphs for mean load carrying capacity v/s W/D, $\mathrm{E} / \mathrm{D}$ and hole diameter

The main effect of the W/D ratio is presented in Figure 14. The Joint bearing strength strongly depends on W/D ratio. By increasing W/D ratio joint strength increases because of increase in area for the joint to sustain the failure. The main effect of the hole diameter presented in the graph fig 5.11. the load carrying capacity of a joint varies from one hole diameter to other.as per the graph hole diameter $7 \mathrm{~mm}$ carries more load than $5 \mathrm{~mm}$ and $8 \mathrm{~mm}$.

\section{E. Response Surface Plots}

The response surface plot is used to predict the response at any zone of the experimentation.
Surface plots for load carrying capacity (with collar)

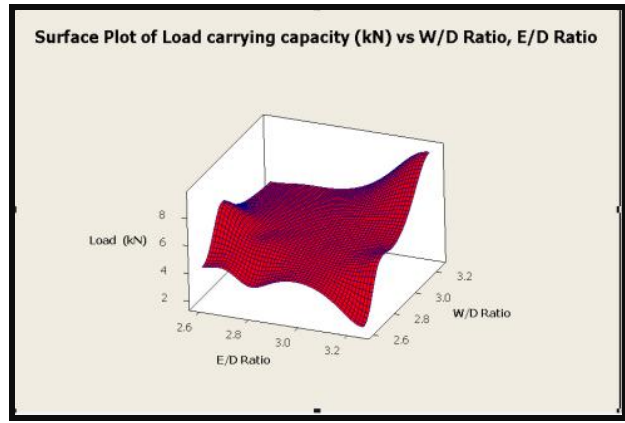

Fig 15 3D surface plot of load carrying capacity v/s E/D and $W / D$ ratio

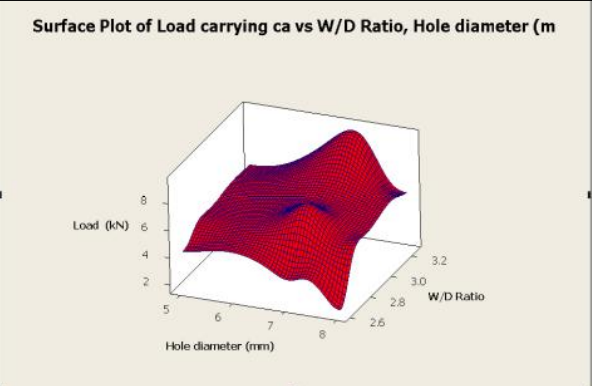

Fig 16 3D surface plot of load carrying capacity v/s hole diameter and $W / D$ ratio

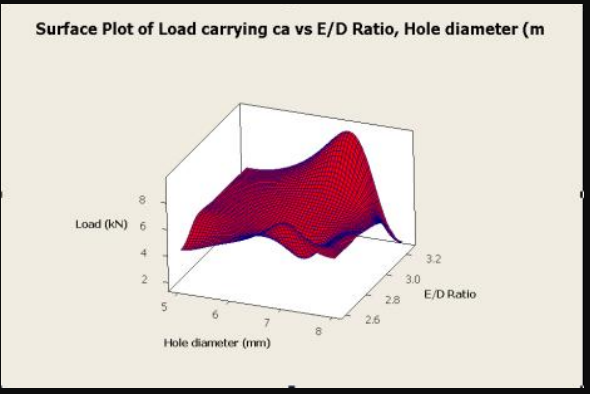

Fig 17 3D surface plot of load carrying capacity v/s hole diameter and $\mathrm{E} / \mathrm{D}$ ratio

Surface plot of load carrying v/s W/D and E/D ratio is shown in the fig 15. it is observed from the figure that as load carrying capacity and bearing strength increases with increasing W/D ratio increases. W/D ratio 3.2 carries more load $95 \mathrm{kN}$ BY and E/D ratio 2.8 carries more load than 3.2. Fig 16 shows that hole diameter slightly influences load carrying capacity and bearing strength hole diameter $7 \mathrm{~mm}$ carries more load than $5 \mathrm{~mm}$ and $8 \mathrm{~mm}$. Fig 17 shows hole diameter and E/D ratio slightly influences on load carrying capacity.

F. Surface plots for load carrying capacity (without collar) 


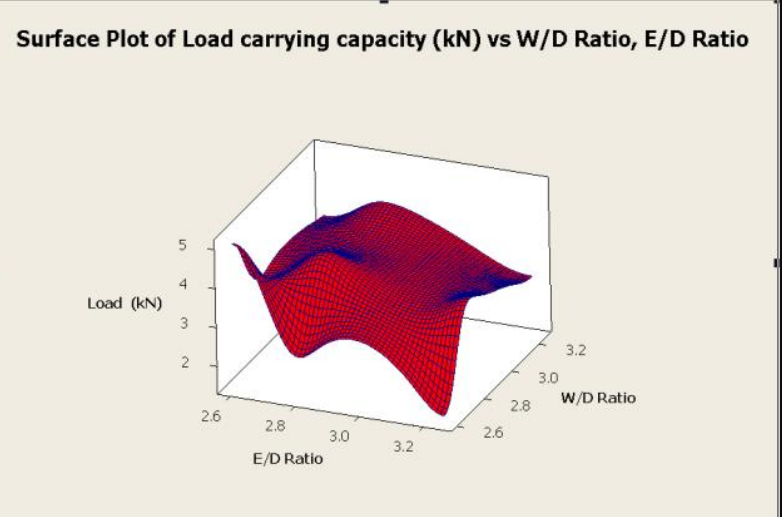

Fig 18 3D surface plot of load carrying capacity v/s E/D and W/D ratio

Surface Plot of Load carrying ca vs W/D Ratio, Hole diameter (m

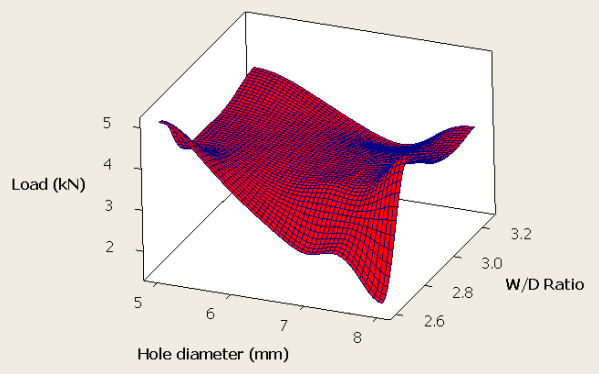

Fig 19 3D surface plot of load carrying capacity v/s hole diameter and $W / D$ ratio

Surface Plot of Load carrying ca vs E/D Ratio, Hole diameter (m

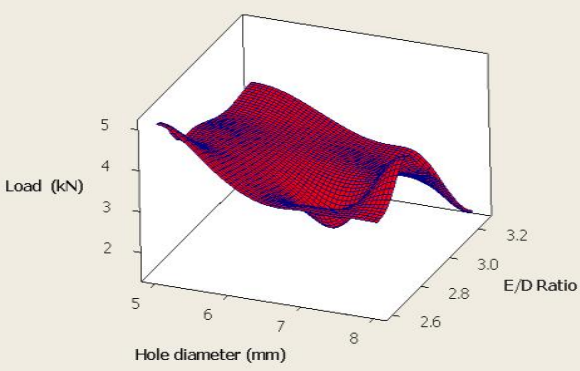

Fig 20 3D surface plot of load carrying capacity v/s E/D and hole diameter

Surface plot of load carrying v/s W/D and E/D ratio is shown in the fig 18 , it is observed from the figure that as load carrying capacity and bearing strength increases with increasing W/D ratio increases. W/D ratio 3.2 carries more load $41 \mathrm{kN}$ and $\mathrm{E} / \mathrm{D}$ ratio 2.8 carries more load than 3.2 ratio.

Fig 19 shows that hole diameter slightly influences load carrying capacity and bearing strength hole diameter $5 \mathrm{~mm}$ carries more load $(41 \mathrm{kN})$ than $7 \mathrm{~mm}$ and $8 \mathrm{~mm}$. Fig 20 shows hole diameter and E/D ratio slightly influences on load carrying capacity.

From above figures we conclude that as W/D ratio increases bearing strength and load carrying capacity increases and E/D and hole diameter slightly influences on bearing strength and load carrying capacity. Using collars which greater influences on bearing strength and load carrying capacity.

\section{CONCLUSIONS}

In this experimental study, an failure analysis was carried out for Single Bolted joint made of jute/epoxy composite considering various parameters such as W/D ratio, E/D ratio and hole diameter to estimate the influence of those on load carrying capacity and bearing strength of composites and failure modes were investigated.

$>$ The bearing strength and load carrying capacity increases with W/D ratio, W/D ratio ranges from 2.8 to 3.25 gives maximum bearing strength and load carrying capacity $(9.5 \mathrm{kN})$ of composite specimen.

$>$ The load carrying capacity of the joint increases with increasing with E/D ratio, 2.6 and 3.25 E/D ratio gives maximum load carrying capacity and bearing strength.

$>$ In this study the hole diameter of $7 \mathrm{~mm}$ carries maximum bearing strength and load carrying capacity than $5 \mathrm{~mm}$ and $8 \mathrm{~mm}$.hence the hole diameter influence is negligible.

$>$ Using the collars in Bolted joints directly influences the bearing strength and load carrying capacity. In this study with collar of 3.25 of W/D and E/D ratio specimen can bear more load and safe the specimen bearing failure mode compared to $3.25 \mathrm{~W} / \mathrm{D}$ and $\mathrm{E} / \mathrm{D}$ ratio of composite specimen without collar. Hence using collar in joints carries more load and avoids sudden failures.

\section{REFERENCES}

1. Krishna K Chawla, "Composite Materials Science and Engineering", $2^{\text {nd }}$ edition, 2006.

2. Jianyu Zhang, Fengrui Liu et.al "Influence of end distances on the failure of composite bolted joints", Journal of Reinforced Plastics \& Composites, 2015,Vol. 34(5), pp. 388-404.

3. Rashmi Gil, Veerendra Kumar et.al "Failure Analysis of Bolted Composite Joint- A" International Journal of Engineering and Technology, May 2014, Volume 11 Number 10, pp. 482-488.

4. Faruk Sen, OnurSayman et.al "Failure response of single bolted composite joints under various preload", Indian Journal of Engineering \& Material Sciences, February 2010, Vol. 17, pp. 39-48.

5. UmranEsendemir "An experimental study of mechanically fastened composites joints with clearance", International Journal of Damage Mechanics, Vol. 20-April 2011, pp. 232-287.

6. 6.Onur Sayman and OzgurAhishali " failure analysis of bolted aluminium sand witch composite plates under compressive load" Journal of Reinforced plastics and composites, Vol.27 .2008 pp. 762-787.

7. AlaattinAktas "Statistical analysis of bearing strength of glass fiber composite materials "Journal of Reinforced plastics and composites, Vol.26 .2007 pp. 375-393.

8. Taner Yilmaz and Tamer Sinmazcelik "Effect of geometric parameters on the pin-bearing strength of glass composites" Journal of composites materials. Vol 43, 2009, pp. 230-278

9. GurbetOrcen, Mustafa Gur et.al "Progressive failure analysis on two parallel Bolted joint glass/epoxy composite plates under the effect of seawater" Journal of Composite Materials, 2014 Vol. 48(28), pp. 3499-3511.

10. Jiefeng Jiang, Yunbo Bi et.al"Influence of interference fit size on hole deformation and residual stress in hi-lock bolt insertion" Journal of Mechanical Engineering Science, 2014, Vol. 228(18), pp. 3296-3305.

11. Sang-Young Kim, Bin He et.al "Bearing strength of interference-fit pin joined glass fiber reinforced plastic composites" Journal of Composite Materials, 2016, Vol. 0(0), pp. 1-13

12. ShimingZu, Zhengong Zhou et.al "Effect of temperature and geometrical parameters on mechanical properties of pin-loaded fiber metal laminate joints" Journal of Composite Materials, 2017, Vol. 51(22), pp. 3163-3173.

13. ManjeetSekhon, JS Saini et.al "Influence of nanoparticle filler content on the bearing strength behaviour of glass fiber-reinforced epoxy composites pin joints" Journal of Materials: Design and Applications, 2015, Vol. $0(0)$, pp. 1-16. 
14. UA Khashaba, TA Sedaey et.al "Experimental and numerical analysis of Bolted -joints composite laminates: Effect of stacking sequences" Journal of Composite Materials, 2012, Vol. 47(27), pp. 3353-3366.

15. Mohsen Feyzi and SoranHassanifard "On the fatigue life prediction of single-lap composite bolted joints" Journal of Composite Materials, 2016, Vol. 50(22), pp. 3157-3172.

16. Murugesh M C, Harsha $\mathrm{H} \mathrm{M}$, Bharath $\mathrm{K} \mathrm{N}$, "Influence of filler material on Bolted joints of woven glass fiber reinforced epoxy composites", Journal of Composites and Biodegradable Polymers, 2013, Vol 1, pp. $47-55$. 